\title{
Islamic Nuance in Decorative-Ornament Architecture Art in Nusantara
}

\author{
Abdullah Yusof ${ }^{*}$ \\ Aizan Hj. Ali @ Mat Zin1 \\ Faisal @ Ahmad Faisal Abd Hamid1 \\ ${ }^{1}$ Department of Islamic History and Civilization \\ Academic of Islamic Studies Department of Islamic History and Civilization, Academy of Islamic \\ Studies Building, University of Malaya, 50603 Kuala Lumpur, Malaysia \\ *Corresponding Author, Email Address: abdy@um.edu.my
}

\begin{abstract}
The advent of Islam in Nusantara sparked new phenomena or changing not only in structure of building construction of religious places, residency and houses but also ornaments and decoration expressing value of beauty of that building. The result of this research tries to reveal how far Islamic influence is working without undermining local aspects of architecture and how Islamic architecture was influenced by other characters in ornament and decorative-ornament artwith various design and sense. Islamic nuances are substantially showed in traditional and contemporary mosque architecture, graveyard, residencies, palaces, historical building and soon and so forth. Although local elementsare clear, and so with Hinduism and Buddhism, animism, colonial influence and other foreign influences including Middle East, Africa, India and China, Islam shows its prominence in interior and exterior ornament as well as its tools.
\end{abstract}

Keywords: Mosque architecture, Islamic art decoration, Malay world.

\section{A. INTRODUCTION}

Among the relic of Islamic civilization as a manifestation of its artistic character in adornment or decoration art is Alhambra in Spain. The palace was first built by Muhammad Yusuf Ibn Nasr or Ibn al-Ahmar. He made Granada as a center of government and built Alhambra palace (hamr), a florid building as its red stone material appeared to be red during twilight (Grabar, 1978). It has popular motto The Is No Conquer but God that is inscribed in the whole wall of Alhambra (Jacobs, 2000). In the reign of Muhammad $V$, the palace is furnished with carved wood as ceiling decoration (Fernandez-puertas , 1997). The ornament of flower-like in Alhambra developed during the tenure of Muhammad VII and Yusuf III (Ibid). Alhambra is among the greatest art work in architecture for its ratio balancing orientation and gains a momentous respect from architects in Spain. Among the important elements of Islamic architecture are:

1. Huge wall, solid, large, has two main doors as a switch element to other rooms. Decoration and wall ornament are mostly arabesque, plant design, calligraphy, geometric shapes, and color motif reflecting sunlight as the feature of Islamic art (Hanafi, 1985). Still in wall is poetry as an adornment and uncontested emblem for every building ever.

2. Pole is usually coated by cubic ceramic and painted wall paper and dotted with arabesque decoration and calligraphy. The pole is round in shape as in Cardova mosque.

3. Room in palace has carved door made from wood and marble with key hole both in its upper and beneath. Window has a cross-cutting long wood between the two sides and has carved wood in the edge and installed trellis in between. 
4. Banel is a half circle or slice of union in shape, furnished by wooded ceiling as good as hanging see hive (Shabbas, 1993).

5. There are four carved in calligraphy or carved stone fences which connecting from one room to the others.

6. Minaret, as an important element, made for defensive fortification; consisting of 30 different size and height.

7. Irrigation system within the palace, public bath room, other tamandan use water following its decoration and ornament.

8. Garden is made perfect with fountains, and hand-made river resembling heaven garden copying Quran model for its flower, fruit and flow hand-made rivers and fountains (Irwin, 2004).

\section{B. METHODOLOGY}

This paper will discuss Islamic decorative-ornament element and substance in architecture, notably Nusantara. Some of this Islamic civilization contribution may be impressed as continuation of styles and creative form in some historical building and Malay traditional houses assimilated with local elements. The influence of Islam appears also in both traditional and modern mosques. It also takes the graveyard and tombs in its influence. Al-Hambra palace is a brilliant summit of decorative-ornament art inspiring architect and constructor in Islamic world. Next observation is directed toward the only complex high study in Malaysia that represents the astonishing Islamic decoration namely ISTAC

\section{Results and Discussion}

\section{Decorative-Ornament Art and its Influence}

\section{a. Old and Historical Building}

Among the main character of Islamic art is its totality and harmony. Islam spreads across different geographic, politics, ethnics and cultures and Islamic art contributes to the life of Muslim. Islamic ideas are expressed in motifs in various Islamic arts such as architecture, calligraphy, metal-work, pottery, textile and so forth, although come from different factors and historical backgrounds (Yahaya, 1988). Decorative-ornament styles are important unite in mosque architecture and it can be seen in cultural background in recent Muslim daily life (Ludin \& Nor, 1995).

In Kuala Lumpur federation, there are old buildings such as Tanah Melayu train station, old Great Pos and great mosque with minarets, doom, statue and calligraphy. Mosque's architecture in Malay world is following traditional architecture as reflected in traditional Malay houses. But since the adoption of Middle East architecture, it is adopted by architecture of those old mosques (lbid). Kampung Laut mosque is clearly an assimilation of Islam and Malay art. Wood made construction resembles Malay vision and multiple banel reflects spiritual journey in tasawuf concepts (Yatim, 1989). The combination or adoption of architecture from countries such as Turkish, Arab, Persia, India, and china created a foundation for part of Islamic architecture in Malaysia either for mosque or commercial building. The influence of Islamic architecture can be seen as follow:

\section{1) Great Mosque of Kuala Lumpur}

The oldest mosque locates in lot 86 Tun Perak street, a meeting point of Gombak and Kelang Rivers (DBKL, 1991). Its construction is inspired by India Muslim community hadil ilham 
A.B.Hubback for its union doom model built in 1909 made of red brick. He gains an inspiration from architecture of India mosque. The building was diwartakan on antique certificate Akta Benda Purba 1976, 13 $3^{\text {th }}$ October 1983 (Chay, 1989).

\section{2) Sultan Abdul Samad Building}

Architecture of the Sultan Abdul Samad Building is designed by A.C.Norman (Mansor, 2002) in Saransenic architecture, a combination of Islam Moorish architecture from India as an appropriate model for Malay world, and is ready to be built in 1897. Its distinct features are three dooms, forecastle and wide gate, a sharp horseshoe model with watch tower hemmed by two small dooms with a round down stairs showing how assertion is important in Islam. The application of the horse shoe arch reputed as one of unique characters of Islamic architecture.

\section{3) Tanah Melayu Train station}

The building was constructed in 1886 and was ready to use in 1900. As Islamic architecture, at the time, was partaken, A.B.Hubback tried to apply Normayang creation in Sultan Abdil Samad to be its decoration.

\section{b. Traditional Malay Houses}

Islam shows its creed with symbol. However, what make islam different is on its prohibition to use sign and statue resembling human figure and animal as it contradicts to Islamic law. Contrasting to Malaysia engravers, Indonesia carver produces a Bali element, god-goddess carved object, peacock etc. Islam uses calligraphic motifs, flora motifs and geometry (Hanafi, 2000) that requires high quality of thought to invent and understand. It is from those concepts Muslims capture all implicit and explicit meanings (Nasir, 1986).

Instead of calligraphy, the carver is inspired by environment in wood carved, values and Islamic elements frequently applied harmonically (Saad, 2001).

\section{1) Floral Motifs}

Malay sculpture touches upon floral element as basic foundation to express beauty and brings symbolic understanding of Malay worldview. The art products, sometimes, are combined with calligraphy to finally become a common wall decoration in Malay houses (Ahmad, 1996). In floral motifs, there is lamp skies motif, giving an illustration on how Islam grows from one place to the other place (Yahya, 1995). Flower motif, such as lotus, epitomizes men's life support. The support in life is Allah and its leaf means for creatures (lbid).

\section{2) Geometric Motif}

This motif is a close set square, sided and round. This carving can be found in traditional Malay houses, culprit and interior adornment of mosque (Ahmad), as the motif was so popular since the advance of Islam. Beside its beauty essence, it has itself symbolic meaning: three sides express atonement and six sides is a heaven figurative (lbid). 


\section{3) Calligraphy Motif}

Calligraphic motif appeared soon after the advance of Islam in Malay World for it related to Qur'an and Islamic development. The motif is commonly adopted in Malay art, especially in sculpture with copying Qur'an letters, prophet Sunnah, wise word from the companion and classical ulama. Carving with calligraphy is confession of Allah swt, exalting His greatness and strengthening community belief as well as giving composure and soul health (lbid).

\section{4) Cosmos Motif}

Although space motifs such as sun, moon, and star, moving cloud, mountain and hill are practically not popular, however, they are frequently combined with carving art including calligraphy of the names of Allah (Asma' al-Husna). Those motifs illustrate a deep meaning nature as creature of God, religious philosophical, exorcist, amulet etc.

\section{5) Figural Motif}

Figural motifs are rooted to Hinduism and Buddhism before the coming of Islam. Considering that Islam develops no figural motif, carver use calligraphic principles of prayer, birds, and aquatic animal with deep specific religious lessons.

\section{c. Old/Traditional Mosque}

The first mosque in Islamic history was built July 28622 AD in Quba. Afterward, many mosques are built ubiquitous in each region including Nusantara. Among traditional mosques in Malay World are Kg Laut mosques, a 250 years old mosque built by a Javanese preacher visiting $\mathrm{Kg}$ laut in his journey to Indochina. It has typically born a resemblance type with great mosque in Demak and other traditional mosques in Melaka with three stages banel called bumbung bertengek(roof). The mosque was constructed using no single brad. It was moved to Nilam Puri in 1976. The next oldest mosque is Ubudiah mosque beside Sultan Perak palace in Bukit Chandan, Kuala Kangsar, and a combination of Islamic architecture from West Asia, North Africa and India-muslim architectures. State sponsored mosque is still traditional in concepts for its main praying room is covered by an umbrella-like concrete. In its wall, there are geometric patterns making possible ventilation work well. It also has bud-like umbrella minarets.

The most beautiful decoration mosque is Ubudiah mosque as it is a mixture of colonial, Moors and India element in its construction. There are 22 minarets (4 huge, 8 simple and 10 small). Its wall is furnished with marble and has terfoil small gate in each minaret. India-Islam influences are best shown in its chatrisand dooms in each minaret. The minaret is actagon for its length decorated octagonal in every four peaks and has pointed roof. It is also famous for its one big doom and other five small dooms. The big doom in main building is made from aluminum. The other two dooms are in women room and the third is in separation room separating women room and main room. The last doom is right above the mihrab (chamber). The other two are in each side of mosque. If we count every doom in each minaret, the mosque has at least approximately 30 dooms. All of the dooms are union-like motif as representation of Mughal influence and has gold color equal to king mosque in Perak. It has many gates and connected pole with horseshoe model expressing Moorish style duplicating Cordova mosque.

Praying room is octagonal and the octagonal plat is facing kiblah and is functioned as mihrab, a precisely copying the grave of Isa Khan, one of Sur dynasty leader in Mughal, in New Delhi (John, 
1977). It also well decorated in wall, floor and ceiling. In its ceiling there are a carved calligraphy of 99 names of Allah, flowers and geometric motifs. The calligraphy combines gold for the letters, blue and white for each side. Ceiling sculptures are the work of an Uzbek carver in 2003. In the font of mihrab, a frame is inscribed with gold calligraphy where a pulpit is a geometric adornment wood. They agree with pond shape, structure of marble floor and similar ornament rugs in the main prayer room. It has also a horseshoe model of window and door with geometric blue and red glass adopting the residence of Gamal al-Din al-Dhazabi (1637) king of Mamluk in Kaherah (Danby, 1955). In the upper part of wall there is a half round shade with red and green geometric glass panel inspired form Ottoman architecture of blue mosque Ahmadiye and Sulaymaniye mosque, in Istanbul.

Kapitan Kling mosque is the oldest mosque in Pinang Island. It derived from India merchant Chauder Mydin Merican or Chauder Mohuddeen Merican or Kader Moh

uddeen, known as Kapitan Kling. There are eight round main poles in praying room surrounded by teen other poles. In the middle of the pole is decorated with geometric and floral motifs. There are one great doom and two moderate dooms and some undersize dooms with brass color and star and crescent moon in the peak as symbol of Islamic greatness. It has a floral, cosmos and calligraphic decorated wood pulpit (Nasir, 1995). The wall is carved geometrically and painted in gray and soft yellow contrast white background. Those carving are worked by Uzbek's carver. In the upper part of pulpit, there is a tulip-like decoration as if it school roof (pengakap).

The minaret is built differently from that in 1910's and uses Mughal architecture and indosaracenic as that in India. In the praying room, leaves decorated rugs are spread as beauty as mosques in $\mathrm{KL}$ federation. What is different is that from generation to generation none is allowed to step on the floor as it is also place to perform shalat. Wall interior decoration has floral motifs, geometry and calligraphy of holly verse from Qur'an, names of Allah and syahadah (the confession of faith).

The following mosque is Kampung Keling mosque. Architecture of the mosque (Hamid, 1998) is combination between traditional, Middle East and India architecture. The early mosque in Melaka is inspired from palace and residencies of aristocracy as mosque in $\mathrm{Kg}$. Peringit in Tukang Emas street, built 15 century and contributed to architecture of Kg Kling mosque in early of 18 century.

Kg Kling mosque initially was building in cooperation between Malayan and India-Muslim in 1748 $A D(1152 \mathrm{H})$. It made from wood and gets several adaptations with still keeping authenticity of its structure of building and banel. The pulpit is semi-rounded shape that built bended inward into the wall; a combination of cube and circle. The pulpit (Ludin) made from berlian wood with lamp skiesornament and flower using sequel and embossed silat perforation technic of carving.

The early mosque is impressed for its no minaret and in Nusantara the first mosque with minaret is Kudus mosque (Yusuf, 1995) inheriting Hinduism architecture. It is so to speak that constructing minaret is inspired from fire tower in Greece. Mosque minaret is a separation building from the main building and has pagoda style for its pointed upward and covered by ridge quartered banel, as an indication of Islamic elements, Hinduism and China. This mosque made from stages banels with intersect roof. Al-Azim mosque (state sponsored mosque) is also uses stage banels despite made from different materials. 


\section{d. Modern and Contemporary Mosque}

One of modern mosque is Putramosque with Persian-Safavid style and architecture. It follows the combination of geometric design, arabesque, calligraphy, lamps, wall adornment and landscape. Geometric design is seen in cengal wood wall, the wall in women praying room, main imam building, windows and also pulpit. Arabesque motif is clearly interior decoration of doom. Motif decorative calligraphic is plated in mihrab wall and upper part of gates as combination of various Arabic handwritings such as nasakh, thuluth and raihani. The verses about the calling for prayer Al-Jumu at verse 9-10 - are well-carved in door gate and calling for faith and god-fearing - Ali 'Imran verse 193-194 as well as al-Baqarah verse 19- are carved in wall of pulpit.

Lamps are set to take after similar model in that of mosque in Iran. The local element in cengal wood interior is a Malay traditional carving. Floral motif in the exterior of main payer room is local component and derives from Sufism aspiration of past Malay people. Each marble ladder has an image of a sunflower figure. Foreign aspect such as Persian style is adopted in all architecture concepts of mosque in Safavid kingdom. The India influence abides in the onion model. Its carving is taken from arabesque model of Egypt.

BesiMosque is decorated in calligraphy, square geometry side, pentagon, hexagon and so forth. In its floral motif, the form is equal to arabesque, a popular decoration in Iran. Besi mosque is named as mosque in garden (Mohyin, 2005). It is then given formal name as Tuanku Mizan Zaenal Abidin mosque. To construct the mosque, all materials cost are RM 200 millions and use 6000 ton of stone and concrete. With modern architecture concept, it loads 20 thousand people and is regarded as the biggest mosque in Southeast Asia. Its interior is decorated with Qur'anic phrase plated in 13 meters high glass. In the right part, a fancy verse of 40-47 of surah Ibrahim is inscribed and in the left verse 148-153 of al Baqarah is plated. The main door which directly connected to main prayer room is carved with verse 80 of al-Isra and the main gate door made from a white concrete with 99 name of Allah relief. Although it is a combination between Germanic and china architecture, the name of Allah appears and clearly visible beyond the doom. Its modern feature can be seen in that the mosque has no minaret.

Construction component of the mosque is a white marble pulpit with Qu'ranic phrase ornaments plated on anti-reflected light pieces of glass or mirror to give an impression as if the verse is floating. Its chamber is also made of the same component. In its doom there is a carved stainless steel with Allah in the middle of the doom with 45 meters in its diameter to reflect seven layers of sky with its different function for each layer. The main room let to be opened to make good ventilation with plain and huge air-gap banel. It makes possible to let the room full with positive, clean and fresh ions. It is light as it has no concrete structure for its steel is fabricated and is constructed before functioning in construction. Sincerity to express the only temporary life is bold on no-wall construction and covered by imported mashrabiyah, a combination of steel matticework and plait of Architectural woven wire mesh, from Germany. Modern aspect appears in ceiling, wall and glazed poles as well as lamps to reflect a commensuration of Islam with progressive modern time.

The gate is so called Imam Malik door, a unique and appealing door carved with 99 name of Allah in each right and left poles as if they fall from heaven for its position is up-down. The five right and left poles epitomizes five prayers as a religious foundation. Its construction is modern in principle, however, it still clearly express character of Islamic architecture. 


\section{e. King Tomb Ornaments}

Installing value to symbol is hard in Islamic art (Allen, 1982) for Islam forbids using symbol or human figure (Yunus) to every human product including artisan work, with exception of calligraphy. It is asserted by Lamya Lois al-Faruqi (al-Faruqi, 1986) that Islam is never tolerant to human figure to avoid falling to polytheism. The carved written in king gravestone (in Jugra, Klang and Shah Alam) is following Arabic and Java letters with adorable patterns (Yatim). For example the repeating sentence (Bamborough, 1976) of la ilaha illallah in king tombs in Slangor set to teach to always remember to Allah for all of visitor when reading it (Bougas, 1988).

A creep plant motif in the form of arabesque can be seen in the gravestone of king graveyard in Selangor, especially in the Jugra hill. The motif is a common ornament in every Persian rug, wall and doom in Sheikh Lutf Allah mosque in Isfahan, Iran. It is clear that the gravestone is religious and expresses Islamic religious symbolism. In Islamic symbolism there are three different patterns to be used that are square to express earth and other natural objects, triangular for human awareness and hexagonal or round for heaven (Critchlow, 1976).

\section{f. Institute of Islamic Thought and Civilization (ISTAC)}

Among the unique building of ISTAC is library, which has rounded ladder. Needham (1969-3) defines that symbol is something that stands for other objects (Yatim, 1989). When round has different meaning for Sufism, it frequently suggests heaven and after life. Critehlow (1983) suggests that round is symbol of main cosmos, unity and harmony (lbid).

Besides, there is a fountain to draw continuity of nature with elements and power such as water, air and light to throw heat and hold cool air at noon (Rahman, 1993). An ornamented replica or lamp skies illustration or arabesque is complex designs consist of different form such as geometry, floral motif and calligraphy. This motif reflects continuity expressing that Allah has no begin and no end attributes (Yatim). Geometric culture, for example, is a cultural heritage allowing artists to develop harmonically specific forms from geometry basis (Nasr, 1989).

Carved object in front of pole wedged in two soft color colonnades, a pale white kalsomine, giving symbolic elements on modesty of Islam and idea of Allah that prefers no pompous and extravagance. Poles are carved with a recursive tulip-like. al-Attas gains inspiration to decorate interior and exterior from al-Hambra, Granada, beautiful mosques in Cordova and Seville, Dome Rock in Jerusalem, Istanbul, Ibn Tulun mosque in Kaherah, Taj Mahal in Agra, ancient building in Spain, North Africa, India, Turkistan and Iran. Surrounding (Persekitaran) that emphasize harmony and beauty is illustrated as the city of Baghdad (Ali, 1992) built by Khalifah al-Mansur in $1454 \mathrm{H}$ or City of Qurtubah (Cardova) constructed under Abd Rahman III (912-963). It was the only beautiful city in the world on its contemporary with half million inhabitant, 600 mosques, 900 public bath (hammam), 50 hospitals, more than 800 schools, and library with 600.000 books' collection as well as 70 private libraries (Ishak, 1980).

For ISTAC, Al-Attas inspires ponds and fountain in the facade of mosque, a typically blue water pond as symbol of luxury, prosperous and cold, a critical element of Islamic garden. The mosque chamber is octagonal made from sturdy timber and cengal trees. It is so with doom (Safarwan), a gleaming floor tile decorated by aquamarine jewelry with Qur'an and Prophet traditon phrases. In addition to minaret (Hamid), there is a meeting room ornamented by geometric forms and flagging horn wood as canopy (muqarnas), a stalactite forms with carrying cloth hanging in the ceiling. The Muqarnas is used as canopy for almost every building in Islamic architecture (al-Attas, 1998). The 
best form of muqarnas ever constructed by Two Sisters council is Alhambra palace, Granada, Spain (Hamid).

\section{CONCLUSION}

Islamic nuance building especially decorative-ornament art is applied in many old and modern building. Those show the prominence of Islamic art adopting variety of ideas to produce beautiful and attractive decoration as the form of love and belief in Allah swt. The inclusive of Islam and ummah appear obviously in preserving beautiful motifs through combination of various elements in the world across culture, ethnic, geography and politics. It creates a foundation of worldwide respect onlslamic art from East to West. Decorative-ornament motifs finally bring human as creature to close to their creator, Allah swt. 


\section{References}

Ahmad, Jasman, et.al. (1996). Ukiran Melayu. Petaling Jaya: Pinang. p. 22.

Al-Attas, Sharifah Shifa. (1998). ISTAC Illuminated. KL: International Institute of Islamic thought and civilization., p. 83 .

Al-Faruqi, Lamya Lois. (1986). The Quranic Arts of Islamic Civilization. p. 40-44.

Ali, Syed Ameer. (1992). Sejarah Evolusi Dan Keunggulan Islam. KL: DBP. p. 462.

Allen, James, W. (1982). Islamic Metalwork. The Es-Said Collection. London : Softheby. p. 9.

Chay, Peter. (1989). KL: Minarets of old, visions of new, Foto Technik Sdn Bhd. p. 36.

Critchlow, Keith. (1976). Islamic Patterns-An Analytical and Cosmological Approach.London: Thames and Hudson. p. 8.

Bamborough, Philip. (1976). Treasures of Islam. Blandford Press, Dorset. , p. 26

Danby, Miles.Moorish Style. (1955). London: Phaidon Press. p. 110.

Fernandez-puertas, Antonio. (1997). The Alhambra From The Ninth Century To Yusuf 1 (1354). London: Saqi Books. p. 3.

Grabar, Oleg. (1978). The Alhambra. London: Penguin Book Ltd. p. 35.

Hanafi, Zulkifli. (1985). Kompendium Sejarah Seni Bina Timur. Pulau Pinang: Penerbit USM. op.cit. p.170.

Hamid, Datuk Rizuan Abd.Masjid, Sejarah, Ciri-Ciri Pembangunan Dan Pembinaan Masjid-Masjid Dunia, Malaysia Dan Kuala Lumpur. KL: puncak awal (M) sdn. Bhd., p. 16.

Hamid, Rizuan Abdul. (1998). Masjid: Sejarah, Ciri-Ciri Pembentukan Dan Pembinaan Masjid Di Dunia. Malaysia dan Kuala Lumpur. KL: Puncak Awal Sdn. Bhd. p. 244.

Hanafi, Zuklifli. (2000). Pola-Pola Hiasan Dalam Bagunan Tradisional Melayu. KL: DBP. p. 19.

Irwin, Robert. (2004). The Alhambra. London: Profile Books Ltd. p. 57;

Ishak,Abdullah Ishak. (1980). Islam Dan IImu Pengetahuan. KL: DBP. p. 188-189.

Jacobs, Michael. (2000). Alhambra. London: Frances Lincoln Ltd. op.cit. p 26.

John, D.H. (1977). Islamic Architecture. New York: Harry N Abrans Ins. Publisher, p 304. This building is known as The Octagonal.

KL Today And Tomorrow. (1991). DBKL Publication. p. 10. 
Li Hua Yen, Mahmud Yusuf. (1995).Masjid-Masjid Di Negara China. terj., Mukhlisin Sa`ad. KL: pustaka antara Sdn. Bhd.

Ludin, Manja Mohd., Nor, Ahmad Suhaimi Mohd. (1995). Aspek-aspek Kesenian Islam. KL: DBP. p. 27

Manja Mohd Ludin, et.al, p. 24.

Mansor, Noorazima Hasmah, el. Al. (2002). Bangunan-Bangunan Bersejarah Di Kuala Lumpur. Perpustakaan KL. p. 54.

Mohyin, Zuarida. (2005). Seni Bina Unik 'Masjid Besi'. Utusan Malaysia. p. 2.

Nasir, Abdul Halim. (1986).Ukiran Kayu Melayu Tradisi. KL: DBP. p. 93.

Nasir,Abdul Halim. (1995). Senibina Masjid Di Dunia Melayu-Nusantara. Bangi: Penerbit UKM. p. 170.

Nasr, S.H. (1989). Falsafah Kesusasteraan Dan Seni Halus. KL: DBP. p. 80.

Q.A. Bougas. (1988). Some Early Islamic Tombstones In Patani. JMBRAS, LIX, I. p. 97.

Rahman, Afzalur. (1993). Ensiklopedia Sirah, Sunnah, Dakwah Dan Islam. jld. 1, KL: DBP, 1993. p. 669.

Saad, Ismail, et. Al. (2001). Spesis-Spesis Kayu Dalam Seni Ukiran Melayu Johor.Penerbit UTM Skudai. p. 13-15.

Safarwan, Zainal Abidin. Kamus Besar Bahasa Melayu Utusan. KL: utusan publication \& distributors sdn. Bhd. p. 943.

Shabbas, Audrey. eds. (1993). A Medieval Banquet in the Alhambra Palace. California: AWAIR. p. 60.

Yahaya,Mahayuddin Haji. (1988). Tamadun Islam. Shah alam: Penerbit Fajar Bakti Sdn. Bhd., p. 431.

Yahya, Muhammad Afandi. (1995).Simbolisme Dalam Seni Bina Rumah Melayu Kelantan. KL: DBP. p. 121. (no year)Simbolisme Dalam Kesenian Islam. Muzium Negara Malaysia.

Yatim,Othman Mohd. (1989). Warisan Kesenian Dalam Tamadun Islam. KL:DBP. , p 75.

Yunus, Mahmud. Tafsir al-Quran al-Karim. surah al-maidah ayat 93. Singapore: Asyraff Trading. p. 167. 